\title{
Agricultural policy-induced landscape changes: effects on carabid abundance and their biocontrol potential
}

\author{
Olga AMEIXA and Pavel KINDLMANN
}

\begin{abstract}
Department of Theoretical Ecology, Institute of Systems Biology and Ecology AS CR and University of South Bohemia, Branišovská 31, CZ-370 05 České Budějovice, Czech Republic; e-mail: olgameixa@portugalmail.pt
\end{abstract}

Key words. Agricultural intensification, biocontrol, density, diversity, species richness, food webs, predatory pressure

\begin{abstract}
One of the most important services provided by biodiversity is thought to be the biological control of pests in agricultural landscapes, including aphids on cereals. The food webs potentially contributing to biological control of aphids primarily consist of polyphagous predators, parasitoids and pathogens. The problems of aphid pests have increased greatly since the 1970-ies, possibly as an effect of agricultural intensification, which is thought to have reduced diversity and abundance of these predators and parasites and consequently their biocontrol potential. The main objective of this study was to test this by measuring this potential for biological control of aphids, and relate it to agricultural intensification and predator abundance. We selected 30 farms distributed along agricultural intensification gradients, based on the amount of fertilizers applied per hectare. Estimates of ground-living predator density were obtained using pitfall trapping over a one-week period. Traps were placed inside the cereal fields, $10 \mathrm{~m}$ from the margin, in 2 replicates per field. Predation risk due to ground-living predators (biocontrol potential) was estimated by monitoring removal of aphids glued to labels. This was done in the same fields, in the immediate vicinity of the traps, over a period of 2 days. The proportion of aphids eaten per unit time was the response variable. We present the correlations between intensity of agricultural exploitation, predator abundance and biocontrol potential. The outcomes are not straightforward in that intensification begets a reduction in predator density and biocontrol potential. We discuss the potential confounding issues that might have affected our results.
\end{abstract}

\section{INTRODUCTION}

Intensive production of cereals comprises about $21 \%$ of European land cover (33.81 millions of ha), corresponding to one third of the total European area devoted to agriculture (European Environmental Agency, 2000). Over the last 50 years, farmland in western European countries has experienced dramatic changes, mainly through the intensification of farming techniques (Siriwardena et al., 2000; Robinson \& Sutherland, 2002) associated with the Common Agricultural Policy (CAP). This has entailed a loss of biodiversity judged to be similar to that expected from climate change. Plants, insects and especially birds have declined at the community level (Pain \& Dixon, 1997; Chamberlain et al., 2000; Söderström \& Pärt, 2000). Several studies suggest that agricultural intensification, farming systems with different intensites or decreased landscape heterogeneity induce biodiversity loss (Robinson \& Sutherland, 2002; Benton et al., 2003; Bengtsson et al., 2005).

The intensification of European agriculture has included three main driving processes: (1) simplification and specialisation of agricultural landscapes leading to a decrease in permanent pastures and semi-natural landscapes, (2) transformation of less fertile areas into shrub and early successional forests, loss of landscape heterogeneity and (3) increase in the use of agricultural chemicals (herbicides, pesticides and fertilizers) per unit area. The species loss in European agricultural landscapes has been the result of changes in the food webs induced by structural habitat modifications or changes in the supply and diversity of the species' resource base. The simplification of agricultural landscapes not only has affected diversity, but also ecosystem services (Thies \& Tscharntke, 1999; Östman et al., 2001, 2003). One of the most important services provided by biodiversity is the biological control of pests in agricultural landscapes (Weisser \& Siemann, 2004). In this context, however, abundance of insect biocontrol agents, rather than their species diversity plays a primary role: more individuals of natural enemies can eat more individuals of insect pests. Thus a decline in the total number of natural enemy individuals negatively affects pest biocontrol.

Among the economically most important insect pests in many parts of Europe are aphids on cereals since they are supposed to be responsible for up to $15 \%$ decrease in yield (reviewed in Leather et al., 1989). Outbreaks of aphid populations causing economic damage have been recorded since the early 1970's, possibly as an effect of agricultural intensification (Thies et al., 2003), especially with the increase of nitrogen fertilizer applications in combination with applications of growth regulators and fungicides (Ankersmit, 1989; Honek, 1991). Chemical control of aphids is expensive, has negative side-effects on the environment and, in addition, it has become increasingly difficult due to increased resistance of aphids to carbamates, organophosphates and other commonly used insecticides. Thus efficient biological control of aphids by natural enemies, if at all possible, is economically valuable for farmers (Östman et al., 2003). The role of natural enemies in preventing cereal aphid outbreaks is questionable and discussed in many studies (e.g., Wratten \& Powell, 1991; Levie et al., 2000; Kindlmann \& Dixon, 

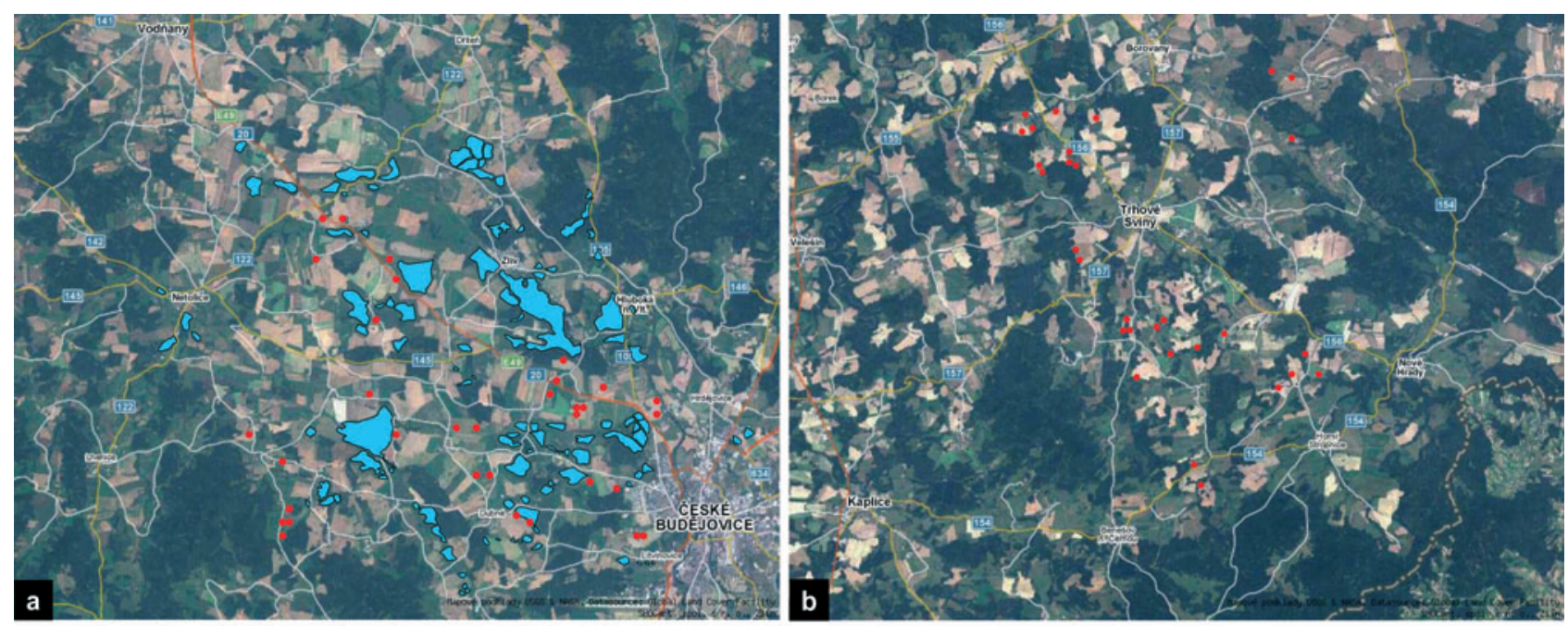

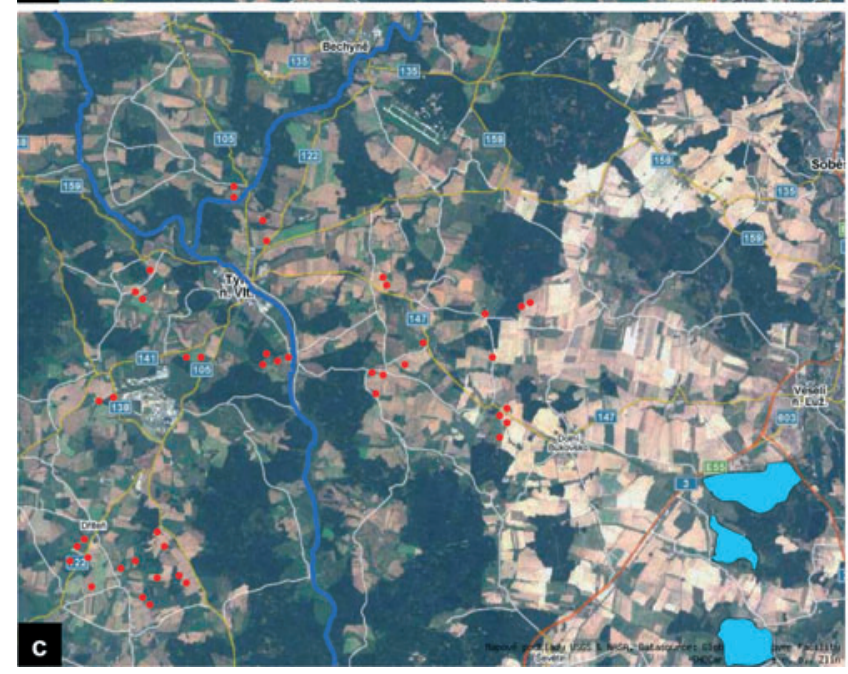

2001, 2004; Sigsgaard, 2002; Schmidt et al., 2003). However, little is known about whether the variability of biocontrol can be explained in terms of the surrounding landscape.

In European agricultural landscapes, the food webs contributing to biological control of aphids primarily consist of polyphagous predators, such as carabids, spiders and ladybirds, and of specialised parasitoids and pathogens, and the relative importance of different taxa has

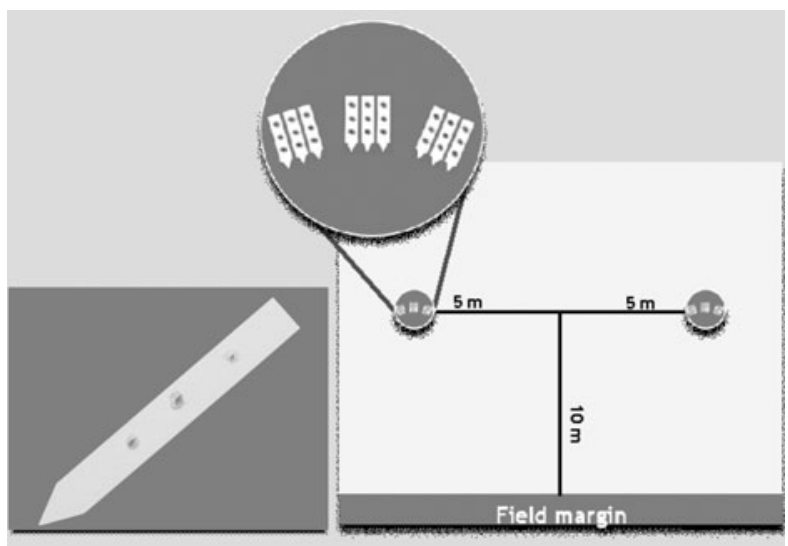

Fig. 2. Experimental setup for estimating the predator pressure.
Fig. 1. Areas where the samples were collected. a - area close to České Budějovice, extremely urbanized with several ponds; $\mathrm{b}$ - area with some forests and meadows close to the fields; c - area with some forest, areas with open water, agricultural fields.

been found to vary across Europe (Östman et al., 2001; Thies et al., 2005). It has been shown that ground-living natural enemies can, to varying degrees, decrease the abundance of the aphid species $R$. padi in cereal fields (e.g., Edwards et al., 1979; Chiverton, 1986; Holland \& Thomas, 1997; Östman et al., 2001; Östman, 2004). Food webs have a strong connection to habitat variation, concerning landscape diversity, since many species depend on semi-natural habitats and field margins. Hence, food

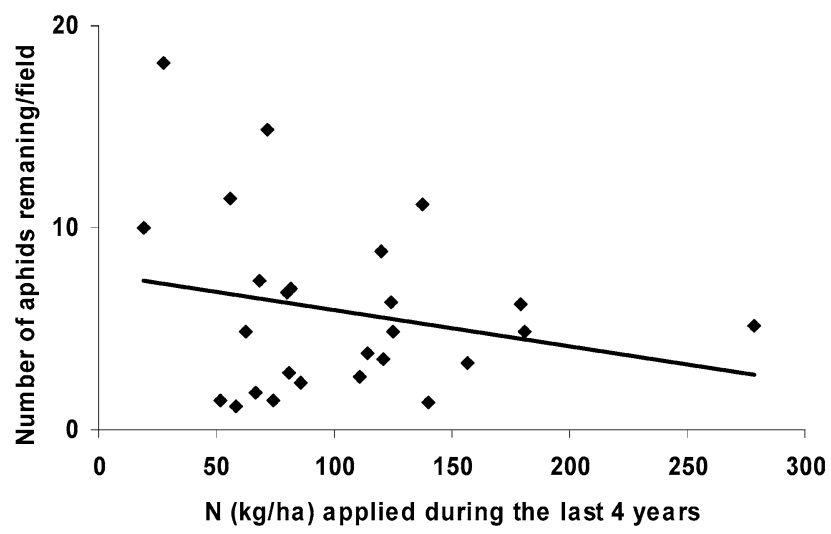

Fig. 3. The average amount of pure $\mathrm{N}(\mathrm{kg} / \mathrm{ha})$ applied per field on the farms over the last 4 years against the average numbers of aphids remaining/field $\left(y=-0.02 x+7.77 ; R^{2}=0.05\right)$. 


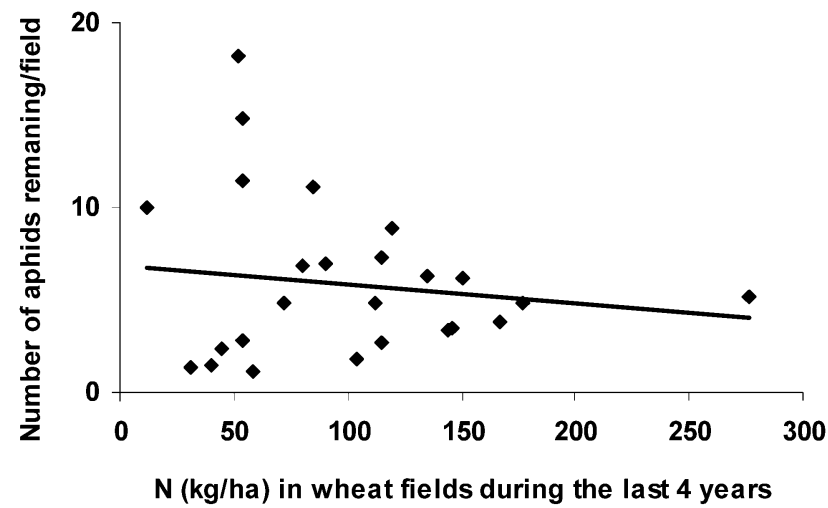

Fig. 4. The average amount of pure $\mathrm{N}(\mathrm{kg} / \mathrm{ha})$ applied to wheat fields over the last 4 years against the average numbers of aphids remaining/field $\left(\mathrm{y}=-0.01 \mathrm{x}+6.91 ; \mathrm{R}^{2}=0.02\right)$.

web structure and topology, patterns of species richness and density of links are likely to vary across landscapes. The loss of natural enemies in agricultural landscapes may ultimately result in a simplification of biocontrol food webs (due to a reduction in intraguild predation) and a reduction in food web complexity. Trophic interactions in aphid-natural enemy food webs will most likely be modified by the changes in landscape structure and diversity induced by the CAP. In addition, the recent reforms of the CAP and the entry of the new EU member countries may have multiple and profound consequences for biodiversity and ecosystem services.

Thus the aim of this work was to study the effects of agricultural intensification on the density of ground living predators in European agricultural landscapes and related to the ecosystem services, like sustained biological control of important agricultural pests, in the case of one new member country, the Czech Republic. More specifically, we have measured the potential for biological control of aphids, and related it to agricultural intensification and predator abundance.

\section{MATERIAL AND METHODS}

This work took place in 90 winter wheat fields, which belonged to 30 different farms. In each farm, information concerning its average altitude and fertilizer inputs over the last 4

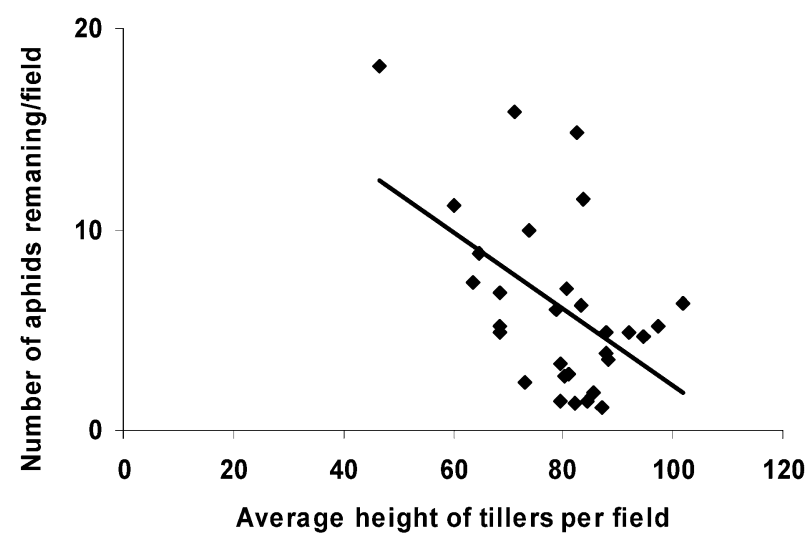

Fig. 5. Relation between the average height of tillers per field and the average numbers of aphids remaining/field $(\mathrm{y}=-0.19 \mathrm{x}$ $\left.+21.4 ; \mathrm{R}^{2}=0.26\right)$.
TABLE 1. Correlation coefficients between the numbers of aphids remaining on the labels and time, and the variables in the first column.

\begin{tabular}{llrc}
\hline Independent & $n$ & $\mathrm{R}$ & $P$ \\
\hline Number of tillers & 90 & 0.01 & $>0.05$ \\
Height of tillers & 90 & -0.41 & $<0.05$ \\
Weed abundance & 90 & 0.26 & $<0.05$ \\
\hline
\end{tabular}

years (average $\mathrm{kg} \mathrm{N} / \mathrm{ha}$ for all fields and average $\mathrm{kg} \mathrm{N} / \mathrm{ha}$ for fields where wheat was grown) was collected. For each field, information concerning presence or absence of various types of surrounding habitats (forest, village, water surface, road) in the vicinity of $500 \mathrm{~m}$ from the field margin and percentage cover of weeds in the field monitored (measured in a $2 \times 2 \mathrm{~m}$ square surrounding each carabid trap) was collected.

The study was conducted in three parts of the České Budějovice region, differing in the type of landscape (Fig. 1a, b, c) covering a total area of about $1625 \mathrm{~km}^{2}$.

The following experiments were conducted when the first winter wheat inflorescence emerged (BBCH).

\section{Predation risk due to ground-living predators (biocontrol potential)}

This was estimated by monitoring the removal of glued aphids in the week May 28 - June 1, 2007. We used Acyrthosiphon pisum, because this species does not attack wheat and therefore we could guarantee to farmers that our experiments would not endanger their crops. Carabids are known to eat any species of aphids they encounter, and therefore the results were not biased.

Three aphids of the L3/L4 were glued to a plastic label $(12 \times$ $1.6 \mathrm{~cm}$ ) with the help of a moist brush (Fig. 2). The labels were then fixed on a polystyrene block to prevent damage during transport to the field. In the field the labels were bent so that the aphids were on the underside to prevent damage caused by rain. In total, 1620 aphids were glued and placed in the field per day; this procedure was repeated three times (a total of 4860 aphids). There were two sampling points per field ( $5 \mathrm{~m}$ apart), at both, 9 labels (27 aphids) were placed $10 \mathrm{~m}$ from the margin of the field (Fig. 2). These labels were checked four times: immediately after being placed in the field, the same afternoon, the morning of the following (second) day and, finally, in the afternoon of the following (second) day. The number of aphids still present on each label was counted. The number of aphids missing at the fourth inspection and the rate of decrease of the number in aphids glued to the labels over the period of the 4 inspections

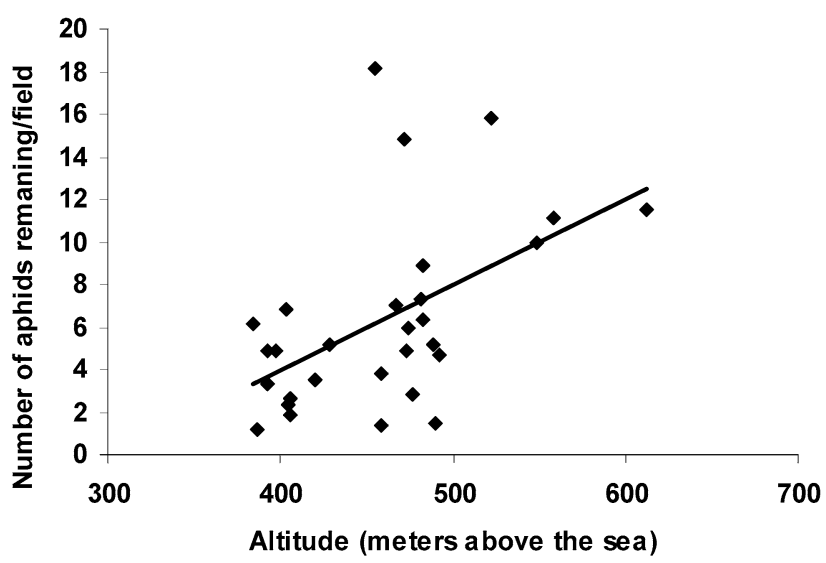

Fig. 6. Relation between altitude and the average numbers of aphids remaining/field $\left(y=6.5 x+417.6 ; \mathrm{R}^{2}=0.26\right)$. 


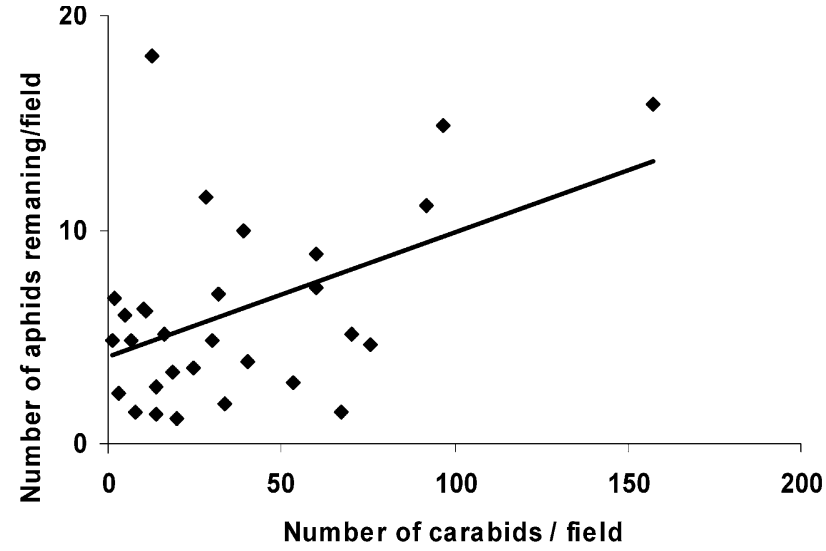

Fig. 7. Relation between the number of carabids captured in pitfall traps and the average numbers of aphids remaining/field $\left(y=0.06 x+4.04 ; R^{2}=0.22\right)$.

(slope of the linear regression between the number of aphids remaining on the labels and time), $S$, were the response variables.

\section{Estimate of the density of ground-living predators (carabid beetles)}

Carabid sampling was done using pitfall traps. A total of 180 traps ( 2 per field) were placed out during the week June 11-15 and emptied one week later. The traps consisted of beer cups and, to protect against precipitation, square roofs (made of aluminium and fixed to soil surface by two nails) were used. The beer cups were placed in a hole made in the ground, after which the surrounding soil was arranged in order to minimize the disturbance of the surface around the trap. During the setting of the traps, another trap container was used to avoid soil and litter falling into the first trap, resulting in cleaner pitfall samples and reducing the time needed to sort. Traps were placed in the ground with the lip flush with the soil surface, since small species could be undersampled if the lip was even slightly above the surface. The traps were filled with a mixture made of water and $10 \%$ ethylene glycol (anti-freeze), to kill the carabids. A drop of unscented washing-up liquid was added to the killing agent in order to reduce the surface tension and prevent animals from escaping. The roof was then placed above the trap. The traps were left in the field for 6 days, after which the contents were collected. To empty the traps without contaminating the fields with ethylene glycol, the contents were filtered through a mesh and placed in a plastic bag and the liquid killing agent collected in a bottle. The carabids were preserved at $-20^{\circ} \mathrm{C}$ until identification. The carabids were identified to species.

\section{Statistical methods}

Standard statistical methods were used for data analyses: linear and multilinear regression (stepwise method) in SPSS, Pearson correlation coefficient, R, two-tailed, two-sample t-test assuming unequal variances and one-way ANOVA.

\section{RESULTS}

\section{Predation risk}

Of the total of 4860 aphids glued to labels and placed in the field, 1579 aphids remained on the labels. The predation rate is the number of aphids missing divided by the initial number of aphids; in this experiment the predation rate was $67.51 \%$.

There was a negative, but insignificant correlation $(R=$ $-0.19, P>0.05$ ) between the number of aphids remaining and the nitrogen input over the past 4 years for the fields of the farms where this study was conducted (Fig. 3). Similarly, there was an insignificant negative correlation $(R=-0.20, P>0.05)$ between the number of aphids remaining and the nitrogen input over the past 4 years for the fields cultivated with wheat (Fig. 4). Thus, in both cases, with increasing nitrogen input, the number of aphids that remained diminished, but not significantly so.

A significant $(R=-0.41, P<0.05)$ negative correlation, explaining $16 \%$ of the variability, was found between the height of the tillers and the number of aphids that remained (Fig. 5, Table 1).

The correlation between the number of aphids remaining and the number of tillers was not significant. The correlation between the number of aphids remaining and weed abundance was positive and significant at the $5 \%$ level (Table 1 ).

There were highly significant $\left(R^{2}=0.26, P<0.01\right)$ positive correlations between the average altitude of the farm and the number of aphids remaining on the labels (Fig. 6) and between the numbers of aphids remaining and the number of carabids captured in the pitfall traps (Fig. 7).

The multiple linear regression in SPSS, using the numbers of aphids remaining as the dependent variable and the nitrogen input over the past 4 years for the fields of the farms where this study was conducted, the nitrogen inputs during the past 4 years in the fields cultivated with wheat, average altitude of the farm, number of carabids captured in the pitfall traps, number of tillers, height of tillers as independent variables, did not reveal anything new: the resulting model contained height of tillers and average altitude of the farm as significant explanatory variables (Tables 2-4).

\section{Diversity and density of ground-living predators:}

A total of 3301 individuals (Table 5), representing 48 different species were collected in the pitfall traps. The carabid assemblages were strongly dominated by the genera Poecilus and Pterostichus, and the dominant species were Poecilus cupreus (36.84\%) and Pterostichus melanarius $(35.72 \%)$.

TABLE 2. Independent variables included in the final multiple linear regression model, with the number of aphids remaining on the labels as dependent variable, as calculated by SPSS.

\begin{tabular}{ccc}
\hline Model & Variables entered & Method \\
\hline 1 & Average height of tillers & Stepwise (Criteria: Probability-of-F-to-enter $<=0.050$, Probability-of-F-to-remove $>=0.100)$. \\
2 & Average altitude & Stepwise (Criteria: Probability-of-F-to-enter $<=0.050$, Probability-of-F-to-remove $>=0.100)$. \\
\hline
\end{tabular}


TABLE 3. Independent variables excluded from the final multiple linear regression model with the number of aphids remaining on the labels as dependent variable, as calculated by SPSS.

\begin{tabular}{|c|c|c|c|c|c|c|}
\hline \multicolumn{7}{|c|}{ Excluded Variables $^{\mathrm{c}}$} \\
\hline \multirow{2}{*}{\multicolumn{2}{|c|}{ Model }} & \multirow{2}{*}{ Beta In } & \multirow{2}{*}{$\mathrm{t}$} & \multirow{2}{*}{ Sig. } & \multirow{2}{*}{ Partial Correlation } & \multirow{2}{*}{$\begin{array}{c}\text { Collinearity Statistics } \\
\text { Tolerance } \\
\end{array}$} \\
\hline & & & & & & \\
\hline \multirow[t]{5}{*}{1} & Nitrogen & $-0.136^{\mathrm{a}}$ & -0.783 & 0.441 & -0.152 & 0.913 \\
\hline & Nitrogen on Wheat fields & $-0.063^{\mathrm{a}}$ & -0.359 & 0.722 & -0.070 & 0.900 \\
\hline & Average altitude & $0.447^{\mathrm{a}}$ & 3.080 & 0.005 & 0.517 & 0.978 \\
\hline & Average number of carabids & $0.432^{\mathrm{a}}$ & 2.912 & 0.007 & 0.496 & 0.960 \\
\hline & Average number of tillers & $-0.242^{\mathrm{a}}$ & -1.466 & 0.155 & -0.276 & 0.953 \\
\hline \multirow[t]{4}{*}{2} & Nitrogen & $0.066^{\mathrm{b}}$ & 0.396 & 0.695 & 0.079 & 0.757 \\
\hline & Nitrogen on Wheat fields & $0.173^{b}$ & 1.032 & 0.312 & 0.202 & 0.728 \\
\hline & Average number of carabids & $0.275^{\mathrm{b}}$ & 1.680 & 0.105 & 0.319 & 0.717 \\
\hline & Average number of tillers & $-0.132^{\mathrm{b}}$ & -0.864 & 0.396 & -0.170 & 0.887 \\
\hline
\end{tabular}

a - Predictors in the Model: (Constant), Average height of tillers; $b$ - Predictors in the Model: (Constant), Average height of tillers, Average altitude; $\mathrm{c}-$ Dependent Variable: Aphids remaining

Positive correlations were found between the number of carabids and number of tillers, number of aphids remaining, and vegetation, and negative ones between the number of carabids and the height of tillers (Table 6). None of them was significant, however.

The average nitrogen input per farm over the last 4 years and the average input of nitrogen per wheat field were negatively, but not significantly $\left(R^{2}=0.04, \mathrm{P}<\right.$ 0.05 ) correlated with the average number of carabids captured (Figs 8 and 9 respectively). The number of carabids per field increased highly significantly $\left(R^{2}=0.27, \mathrm{P}<\right.$ 0.01 ) with increase in altitude (Fig. 10).

The multiple linear regression in SPSS, using the numbers of carabids captured in the pitfall traps as the dependent variable and the number of aphids remaining, the nitrogen input over the past 4 years for the fields of the farms where this study was conducted, the nitrogen input over the past 4 years for the fields planted with wheat, average altitude of the farm, number of tillers and height of tillers as independent variables, also did not reveal anything new: the resulting model contained only the number of aphids remaining as the sole significant explanatory variable (Tables 7-9).

\section{Surrounding landscape}

Most of the fields were located near a road $(91.1 \%)$ or a village $(77.8 \%) ; 45.6 \%$ of the fields were close to forests and $55.6 \%$ were close to water surfaces, like ponds, creeks, or rivers. Most of the carabids captured were in fields near forests (Fig. 11), but there were no significant differences (One-way ANOVA, $P=0.810$; df $=3$ ), between the average numbers caught in fields close to different types of habitats.

In order to analyse a possible relation between the surrounding landscape and the number of carabids caught, a series of two-tailed t-tests, assuming unequal variances, were conducted. There was no significant influence of the presence of a forest close to the field $(P=0.08$; df $=58)$, or a water surface, on the number of carabids caught $(P=$ 0.19 ; $\mathrm{df}=88$ ). However, there was a significant influence of the presence of human settlements close to the field on the number of carabids caught $(P=0.02 ; \mathrm{df}=81)$.

Of all the carabids trapped, $9.1 \%$ were herbivorous and $90.9 \%$ carnivorous. There was no significant influence of the presence of a forest close to a field on the number of carnivorous $(P=0.11 ; \mathrm{df}=54)$ and herbivorous $(P=$ 0.35 ; df $=86)$ carabids caught, or the presence of a water surface $(P=0.11 ; \mathrm{df}=88)$ and $(P=0.28 ; \mathrm{df}=46)$, respectively or the presence of a $\operatorname{road}(P=0.84 ; \mathrm{df}=9)$ and $(P=0.32$; $\mathrm{df}=34)$, respectively. A significant influence of the presence of human settlements was found on the capture of carnivorous $(P=0.03$; $\mathrm{df}=85)$, but not herbivorous $(P=0.28 ; \mathrm{df}=64)$ carabids.

TABLE 4. Coefficients of the final multiple linear regression model with the number of aphids remaining on the labels as dependent variable and their significance, as calculated by SPSS.

\begin{tabular}{|c|c|c|c|c|c|c|}
\hline \multicolumn{7}{|c|}{ Coefficients $^{\mathrm{a}}$} \\
\hline \multirow{2}{*}{\multicolumn{2}{|c|}{ Model }} & \multicolumn{2}{|c|}{ Unstandardized Coefficients } & \multirow{2}{*}{$\frac{\text { Standardized Coefficients }}{\text { Beta }}$} & \multirow{2}{*}{$\mathrm{t}$} & \multirow{2}{*}{ Sig. } \\
\hline & & $\mathrm{B}$ & Std. Error & & & \\
\hline \multirow[t]{2}{*}{1} & (Constant) & 21.509 & 4.855 & & 4.430 & 0.000 \\
\hline & Average height of tillers & -0.191 & 0.061 & -0.519 & -3.159 & 0.004 \\
\hline \multirow[t]{3}{*}{2} & (Constant) & 3.488 & 7.223 & & 0.483 & 0.633 \\
\hline & Average height of tillers & -0.167 & 0.053 & -0.454 & -3.129 & 0.004 \\
\hline & Average altitude & 0.035 & 0.011 & 0.447 & 3.080 & 0.005 \\
\hline
\end{tabular}

a. Dependent Variable: Aphids remaining. 
TABLE 5. Species lists and percentage abundances of Carabidae captured $(\mathrm{C}=$ carnivorous carabids; $\mathrm{H}=$ herbivorous carabids $)$.

\begin{tabular}{|c|c|c|c|}
\hline Carabid species & Feeding preference & Number of individuals collected & $\%$ \\
\hline Agonum muelleri & $\mathrm{C}$ & 13 & 0.39 \\
\hline Agonum sexpunctatum & $\mathrm{C}$ & 53 & 1.61 \\
\hline Agonum viduum & $\mathrm{C}$ & 1 & 0.03 \\
\hline Amara aenea & $\mathrm{H}$ & 5 & 0.15 \\
\hline Amara aulica & $\mathrm{H}$ & 2 & 0.06 \\
\hline Amara bifrons & $\mathrm{H}$ & 1 & 0.03 \\
\hline Amara eurynota & $\mathrm{H}$ & 5 & 0.15 \\
\hline Amara littorea & $\mathrm{H}$ & 3 & 0.09 \\
\hline Amara lunicollis & $\mathrm{H}$ & 10 & 0.30 \\
\hline Amara plebeja & $\mathrm{H}$ & 18 & 0.55 \\
\hline Anchomenus dorsalis & $\mathrm{C}$ & 49 & 1.48 \\
\hline Anisodactylus binotatus & $\mathrm{C}$ & 3 & 0.09 \\
\hline Anisodactylus signatus & $\mathrm{H}$ & 1 & 0.03 \\
\hline Bembidion femoratum & $\mathrm{C}$ & 1 & 0.03 \\
\hline Bembidion lampros & $\mathrm{C}$ & 26 & 0.79 \\
\hline Bembidion lunulatum & $\mathrm{C}$ & 0 & 0.00 \\
\hline Bembidion quadrimaculatum & $\mathrm{C}$ & 2 & 0.06 \\
\hline Bembidion tetracolum & $\mathrm{C}$ & 1 & 0.03 \\
\hline Brachinus explodens & $\mathrm{C}$ & 1 & 0.03 \\
\hline Calathus fuscipes fuscipes & $\mathrm{H}$ & 108 & 3.27 \\
\hline Calathus melanocephalus & $\mathrm{C}$ & 5 & 0.15 \\
\hline Carabus auronitens & $\mathrm{C}$ & 1 & 0.03 \\
\hline Carabus granulatus & $\mathrm{C}$ & 76 & 2.30 \\
\hline Carabus scheidleri scheidleri & $\mathrm{C}$ & 78 & 2.36 \\
\hline Carabus violaceus violaceus & $\mathrm{C}$ & 2 & 0.06 \\
\hline Clivina collaris & $\mathrm{C}$ & 4 & 0.12 \\
\hline Cychrus caraboides caraboides & $\mathrm{C}$ & 1 & 0.03 \\
\hline Harpalus affinis & $\mathrm{H}$ & 49 & 1.48 \\
\hline Harpalus luteicornis & $\mathrm{H}$ & 2 & 0.06 \\
\hline Harpalus signaticornis & $\mathrm{H}$ & 6 & 0.18 \\
\hline Harpalus tardus & $\mathrm{C}$ & 4 & 0.12 \\
\hline Loricera pilicornis pilicornis & $\mathrm{C}$ & 5 & 0.15 \\
\hline Notiophilus palustris & $\mathrm{C}$ & 1 & 0.03 \\
\hline Patrobus atrorufus & $\mathrm{C}$ & 1 & 0.03 \\
\hline Platynus assimilis & $\mathrm{C}$ & 13 & 0.39 \\
\hline Poecilus cupreus & $\mathrm{C}$ & 1216 & 36.84 \\
\hline Poecilus lepidus & $\mathrm{C}$ & 5 & 0.15 \\
\hline Poecilus versicolor & $\mathrm{C}$ & 215 & 6.51 \\
\hline Pseudoophonus rufipes & $\mathrm{H}$ & 76 & 2.30 \\
\hline Pseudoophus griseus & $\mathrm{C}$ & 2 & 0.06 \\
\hline Pterostichus melanarius & $\mathrm{C}$ & 1179 & 35.72 \\
\hline Pterostichus niger & $\mathrm{C}$ & 40 & 1.21 \\
\hline Pterostichus strenuиs & $\mathrm{C}$ & 1 & 0.03 \\
\hline Pterostichus vernalis & $\mathrm{C}$ & 0 & 0.00 \\
\hline Stomis pumicatus & $\mathrm{C}$ & 1 & 0.03 \\
\hline Synuchus vivalis vivalis & $\mathrm{C}$ & 0 & 0.00 \\
\hline Trechus obtusus obtusus & $\mathrm{C}$ & 1 & 0.03 \\
\hline Trechus quadristriatus & $\mathrm{H}$ & 14 & 0.42 \\
\hline Total & & 3301 & 100.00 \\
\hline
\end{tabular}

\section{DISCUSSION}

\section{Predation risk}

One could expect a higher predation pressure in more fertilized fields, because the higher content of $\mathrm{N}$ in the soil might influence the community of weeds and the diversity of plants, thus providing a more heterogeneous food supply for the carabids (Deng, 1983; Deng et al., 1985; Zhang \& Zhao, 1996), which then become more numerous and consequently eat more aphids. Our results were qualitatively consistent with this expectation, but not significant, so we can neither support, nor reject this hypothesis.

The height of tillers was negatively correlated with the number of aphids that remained. This may be because the vegetation height and density might influence the microclimate near the ground, and create more humid microen- 
TABLE 6. Correlation coefficients between the total numbers of carabids captured and the variables in the first column.

\begin{tabular}{lccc}
\hline Independent & $\mathrm{n}$ & $\mathrm{R}$ & $\mathrm{P}$ \\
\hline Number of tillers & 90 & 0.10 & $>0.05$ \\
Height of tillers & 90 & -0.17 & $>0.05$ \\
Number of aphids remaining & 90 & 0.26 & $>0.05$ \\
Weed abundance & 90 & 0.15 & $>0.05$ \\
\hline
\end{tabular}

vironment, which is favourable for carabids (e.g. Gardner et al., 1997; Ings \& Hartley, 1999).

There was a positive correlation between the abundance of weeds and the number of aphids that remained, which is probably due to the fact that a high density of weeds make dispersion more difficult for the carabids and therefore they might be less effective in finding aphids (Greenslade, 1964; Southwood, 1978).

Altitude of the fields was also positively correlated with the predatory pressure. One might hypothesize that at high altitudes the fields are more humid, which causes a higher abundance of weeds, which in turn is important for the presence of some predators, especially carabids (Niemelä et al., 1992; Magura et al., 1997, 2000). Recent evidence suggests that many plant species at higher altitudes are able to photosynthesize more efficiently than their counterparts at lower elevations (Korner \& Diemer, 1994; Diemer \& Korner, 1996; Cordell et al., 1999), become more attractive for phytophagous insects, and so increase the range of different kinds of food available for the carnivorous carabids.

The most interesting result is the positive correlation between the number of aphids that remained and the number of carabids captured in the pitfall traps. This seems to contradict other studies that refer to carabids as biocontrol agents of aphids (Edwards et al., 1979; Chiverton, 1986; Holland \& Thomas, 1997; Östman et al., 2001). One has to bear in mind, however, that the predatory pressure and carabid numbers were determined at different (even if close) times. This result deserves more careful analysis, which we plan to do in the future.

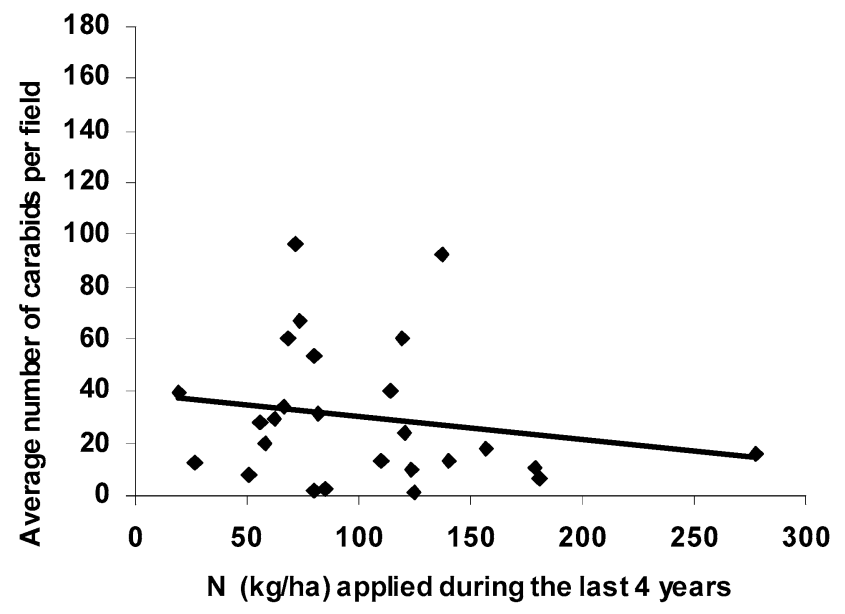

Fig. 8. The average input of $\mathrm{N}$ in $\mathrm{kg} / \mathrm{ha}$ applied per farm over the last 4 years against the average numbers of carabids caught per field $\left(\mathrm{y}=-0.09 \mathrm{x}+39.8 ; \mathrm{R}^{2}=0.04\right)$.

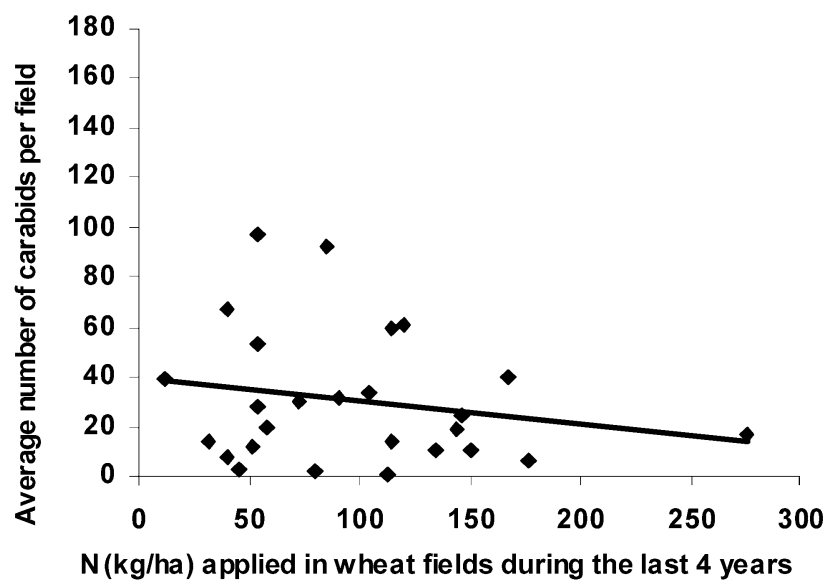

Fig. 9. The average input of $\mathrm{N}$ in $\mathrm{kg} / \mathrm{ha}$ applied per farm over the last 4 years to wheat fields against the average numbers of carabids caught per field $\left(y=-0.09 x+39.4 ; \mathrm{R}^{2}=0.04\right)$.

\section{Diversity and density of ground-living predators}

In total, 48 different carabid species were captured. The most abundant were Poecilus cupreus and Pterostichus melanarius, both generalists, widespread and carnivorous species. P. cupreus is reported to prefer eating aphids, and is considered to be a potentially important biological control agent (Ekbom \& Wiktelius, 1985; Chiverton, 1988; Ekbom et al., 1992).

It is rather surprising that the average input of nitrogen applied over the last 4 years, both for all the fields of a farm, and those where wheat was grown, were not significantly negatively correlated with the number of carabids captured, because Liu et al. (2006), found that the nitrogen content of the soil influences the occurrence of carabids and suggests three explanations for this. (1) Extremely high levels of nitrogen input in agroecosystems may lead to a homogenization of habitat conditions and subsequent disappearance of carabid species. (2) High levels of nitrogen may be toxic to plants, including weeds, consequently resulting in a low density of weeds and carabids. (3) Medium levels of nitrogen could influence the growth of plants and contribute to an increase in weeds and the number of tillers, which may

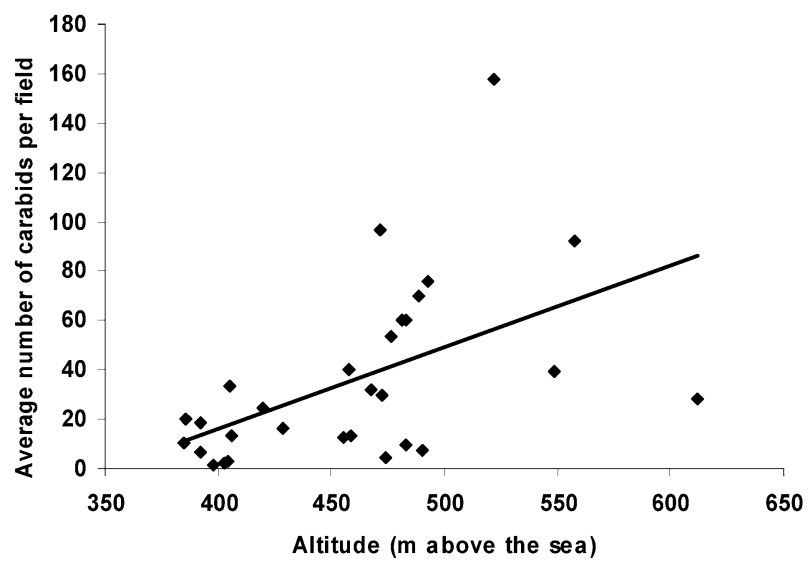

Fig. 10. Altitude against the average numbers of carabids caught per field $\left(\mathrm{y}=0.33 \mathrm{x}-115.6 ; \mathrm{R}^{2}=0.27\right)$. 
Fig. 7. Relation between the number of carabids captured in pitfall traps and the average numbers of aphids remaining/field $(\mathrm{y}=$ $0.06 \mathrm{x}+4.04 ; \mathrm{R}^{2}=0.22$ ).

\begin{tabular}{ccc}
\hline Model & Variables Entered & Method \\
\hline 1 & Aphids remaining & Stepwise (Criteria: Probability-of-F-to-enter $<=0.050$, Probability-of-F-to-remove $>=0.100)$. \\
\hline
\end{tabular}

Fig. 8. The average input of $\mathrm{N}$ in $\mathrm{kg} / \mathrm{ha}$ applied per farm over the last 4 years against the average numbers of carabids caught per field $\left(\mathrm{y}=-0.09 \mathrm{x}+39.8 ; \mathrm{R}^{2}=0.04\right)$.

\begin{tabular}{|c|c|c|c|c|c|}
\hline \multicolumn{6}{|c|}{ Coefficients $^{\mathrm{a}}$} \\
\hline \multirow{2}{*}{ Model } & \multicolumn{2}{|c|}{ Unstandardized Coefficients } & \multirow{2}{*}{$\begin{array}{c}\text { Standardized Coefficients } \\
\text { Beta }\end{array}$} & \multirow{2}{*}{$\mathrm{t}$} & \multirow{2}{*}{ Sig. } \\
\hline & $\mathrm{B}$ & Std. Error & & & \\
\hline $1 \quad$ (Constant) & 8.927 & 10.247 & & 0.871 & 0.391 \\
\hline Aphids remaining & 4.211 & 1.334 & 0.519 & 3.158 & 0.004 \\
\hline
\end{tabular}

${ }^{a}$ Dependent Variable: Average number of carabids.

TABLE 9. Coefficients of the final multiple linear regression model with the carabids captured in the pitfall traps as dependent variable and their significance, as calculated by SPSS.

\begin{tabular}{|c|c|c|c|c|c|c|}
\hline \multicolumn{7}{|c|}{ Excluded Variables $^{\mathrm{b}}$} \\
\hline \multirow{2}{*}{ Model } & & \multirow{2}{*}{ Beta In } & \multirow{2}{*}{$\mathrm{t}$} & \multirow{2}{*}{ Sig. } & \multicolumn{2}{|c|}{ Collinearity Statistics } \\
\hline & & & & & Partial Correlation & Tolerance \\
\hline \multirow[t]{5}{*}{1} & Nitrogen & $-0.235^{\mathrm{a}}$ & -1.399 & 0.174 & -0.265 & 0.923 \\
\hline & Nitrogen on wheat fields & $-0.238^{\mathrm{a}}$ & -1.442 & 0.161 & -0.272 & 0.951 \\
\hline & Average altitude & $0.340^{\mathrm{a}}$ & 1.855 & 0.075 & 0.342 & 0.736 \\
\hline & Average number of tillers & $0.160^{\mathrm{a}}$ & 0.964 & 0.344 & 0.186 & 0.986 \\
\hline & Average height of tillers & $0.095^{\mathrm{a}}$ & 0.485 & 0.632 & 0.095 & 0.730 \\
\hline
\end{tabular}

a Predictors in the Model: (Constant), Aphids remaining; ${ }^{\mathrm{b}}$ Dependent Variable: Average number of carabids.

lead to decreased beetle dispersal within crops, and their decrease in effectiveness at catching aphids (Greenslade, 1964; Southwood, 1978). Also Kromp (1990) related the abundances of Amara spp. to weeds.

Crops with greater cover early in the season like winter barley, winter wheat, and peas appear to be more favourable for carabid beetles than late and open crops such as sugar beet, onions or carrots (Hance, 1990; Booij \& den Nijs, 1992; Booij \& Noorlander, 1992). These authors also observed that crop type affects ground beetle activity/density. After an application of extremely high doses of nitrogen, the carnivorous carabid species Pterostichus melanarius, Bembidion lampros and the herbivorous Amara plebeja avoided the plots with the highest concentrations, accumulating mainly in the non-fertilized

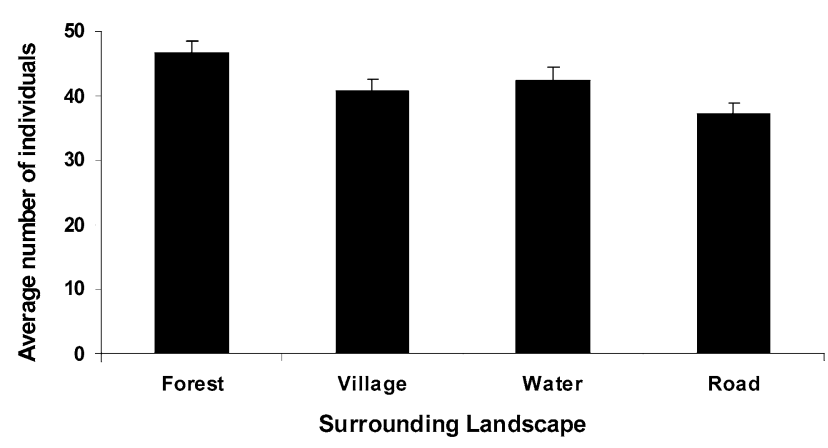

Fig. 11. Average numbers of carabids (+S.E.) captured within fields surrounded by different kinds of landscape. control plots (Honczarenko, 1975). However, in another study Pterostichus melanarius seemed to increase in response to an application of nitrogen (Kromp, 1990). Therefore, nitrogen could influence both carnivorous and herbivorous carabid species both positively and negatively. We did not find a significant correlation (negative or positive) between the amount of nitrogen applied and the number of carabids caught.

Carabid communities are a reflection of the geographic location of the sites (Coll \& Bolger, 2007). We found a positive correlation between the average number of carabids captured per field and the altitude of the field. This accords with other studies, which found differences in species composition of carabid beetle assemblages below $450 \mathrm{~m}$ and above $800 \mathrm{~m}$ (Butterfield, 1996). This could be related to microclimate conditions that vary with altitude, since beetle activity is correlated with humidity and air temperature (Rivard, 1966; Honěk, 1988; Nève, 1994).

\section{Surrounding landscape}

The largest captures of carabids were made in fields near forests, probably because forests are ideal for most carabid species. Gilbert (1989) and Niemelä (1999), claim that urbanisation is the cause of several forms of disturbance (alteration, fragmentation and isolation of indigenous habitats, temperature, moisture, edaphic conditions and pollution), but our one-way ANOVA test demonstrated that the density of carabids in the fields near roads 
or villages was not affected by disturbance caused by urbanization. We captured more carabids in these fields than in those near semi-natural or natural landscapes.

The assemblages of carabids captured included individuals that are typical of different habitats, like forests or open-habitats and some species are generalists for all kinds of habitats. This could explain the significant results of our t-test for the presence of villages. Magura et al. (2004) also obtained results that did not support the hypothesis that overall diversity should decrease in disturbed habitats, and the overall species richness of carabids was almost as high in the urban as in the rural area. Urban habitats are frequently more floristically diverse than less urbanised areas (Tonteri \& Haila, 1990), reflecting the diverse, mosaic nature of urban habitats and the presence of introduced plants. Vegetation structure and the resulting changes in microclimate (e.g., temperature and air moisture) are probably the two most important factors controlling the distribution of carabids (Niemelä et al., 1992; Magura et al., 1997, 2000). Herb cover can also increase the amount of invertebrate prey available for predatory carabids (Niemelä \& Spence, 1994; Niemelä et al., 1994, 1996).

Most of the species caught were carnivorous. This could be important for biological control of aphids, while the herbivorous species could potentially have an important role in biological control of weeds (Kromp, 1999).

\section{CONCLUSIONS}

This study reveals no clear evidence that agricultural intensification (nitrogen fertilization and disturbance of the surrounding landscape) leads to a decrease in carabid abundance, which is counterintuitive and invites further research. The negative correlation between the rate of disappearance of glued aphids from the labels and the number of carabids captured is also counterintuitive and indicates that more attention should be paid to the method used, as aphid disappearance from the labels could have been due to other predators. Most carabids are unable to climb the labels, and reach the aphids. They usually eat aphids that have fallen from the tillers in order to escape form other predators. Thus in order to understand the role of carabids in aphid mortality in wheat fields, probably other experiments need to be designed, or at least the "glued aphid" method rigorously tested.

ACKNOWLEDGEMENTS. This research was supported by the grant No. DIV/06/E013 of the GA ČR, grant No. LC06073 of the MŠMT and by the grant No. A6087301 of the GA AV ČR.

\section{REFRENCES}

AnKersmit G.W. 1989: Integrated control of cereal aphids. In Minks A.K. \& Harrewijn P. (eds): Aphids, Their Biology, Natural Enemies and Control. Vol. 2C. Elsevier, Amsterdam, pp. 273-277.

Bengtsson J., Ahnstrom J. \& Weibull A.C. 2005: The effects of organic agriculture on biodiversity and abundance - a metaanalysis. J. Appl. Ecol. 42: 261-269.

Benton T.G., Vickery J.A. \& WiLSON J.D. 2003: Farmland biodiversity: is habitat heterogeneity the key? TREE 18: 182-188.
Boolj C.J. \& DEN Niss L.J.F.M. 1992: Agroecological infrastructure and dynamics of carabid beetles. Proc. Exp. Appl. Entomol. 3: 72-78.

Booij C.J.H. \& Noorlander J. 1992: Farming systems and insect predators. Agr. Ecosyst. Envir. 40: 125-135.

Butterfield J. 1996: Carabid life-cycle strategies and climate change: a study on an altitude transect. Ecol. Entomol. 21: 9-16.

Chamberlain D.E., Fuller R.J., Bunce J.C., Duckworth J.C. \& Shrubi M. 2000: Changes in the abundance of farmland birds in relation to the timing of agricultural intensification in England and Wales. J. Appl. Ecol. 37: 771-788.

Chiverton P.A. 1986: Predator density manipulation and its effects on polyphagous and aphid specific predators in spring barley. J. Appl. Entomol. 109: 49-60.

Chiverton P.A. 1988: Searching behavior and cereal aphid consumption by Bembidion lampros and Pterostichus cupreus, in relation to temperature and prey density. Entomol. Exp. Appl. 47: $173-182$.

Coll M.T. \& Bolger T. 2007: Biodiversity and species composition of Carabidae in Irish coniferous forests: additional insight from the use of paired sites in comparisons with the fauna of open habitats. Biology and Environment: Proc. $R$. Irish Acad. (B) 107 (1): 1-11.

Cordell S., Goldstein G., Meinzer F.C. \& Handley L.L. 1999: Allocation of nitrogen and carbon in leaves of Metrosideros polymorpha regulates carboxylation capacity and delta C-13 along an altitudinal gradient. Funct. Ecol. 13: 811-818.

Deng D.A. 1983: The feeding habits of thirteen species of ground beetles (Coleoptera: Carabidae). Acta Entomol. Sin. 3: 356-357.

Deng D.A., Wang G.Q. \& Li J. 1985: Bionomics of predacious carabids in Heilongjiang. Acta Entomol. Sin. 3: 281-286.

Diemer M.C. \& KorNer C. 1996: Lifetime leaf carbon balances of herbaceous perennial plants from low and high altitudes in the central Alps. Funct. Ecol. 10: 33-43.

Edwards C.A., Sunderland K.D. \& George K.S. 1979: Studies on polyphagous predators of cereal aphids. J. Appl. Ecol. 16: 811-823.

Еквом B.S. \& Wiktelius S. 1985: Polyphagous arthropod predators in cereal crops in central Sweden 1979-1982. Z. Ang. Entomol. 99: 433-442.

Еквом B.S., Wiktelius S. \& Chiverton P.A. 1992: Can polyphagous predators control the bird cherry-oat aphid (Rhopalosiphum padi) in spring cereals? Entomol. Exp. Appl. 65: 215-223.

European Environmental Agency 2000. http://www.eea. europa.eu.

Gardner S.M., Hartley S.E., Davies A. \& Palmer S.C.F. 1997: Carabid communities on heather moorlands in northeast Scotland: the consequences of grazing pressure for community diversity. Biol. Conserv. 81: 275-286.

Gilbert O.L. 1989: The Ecology of Urban Habitats. Chapman \& Hall, London, 369 pp.

GREensLlade P.J.M. 1964: Pitfall trapping as a method for studying populations of Carabidae (Coleoptera). J. Anim. Ecol. 33: 103-110.

HANCE T. 1990: Relationships between crop types, carabid phenology and aphid predation in agroecosystems. In Stork N.E. (ed.): The Role of Ground Beetles in Ecological and Environmental Studies. Intercept, Andover, pp. 55-64.

Holland J.M. \& Thomas S.R. 1997: Quantifying the impact of polyphagous invertebrate predators in controlling cereal aphids in preventing wheat yield and quality reductions. Ann. Appl. Biol. 131: 375-397. 
Honczarenko J. 1975: An influence of high-dose nitrogen fertilizer on the entomofauna of meadow soil. Pedobiologia 16: 58-62 [in Russian, with English abstr.].

HoNĚK A. 1988: The effect of crop density and microclimate on pitfall trap catches of Carabidae, Staphylinidae (Coleoptera), and Lycosidae (Araneae) in cereal fields. Pedobiologia 32: 233-242.

HoNĚK A. 1991: Nitrogen fertilization and abundance of the cereal aphids Metopolophium dirhodum and Sitobion avenae (Homoptera: Aphididae). Z. Pflkrank. Pflschutz 98: 655-660.

IngS T.C. \& HARTLEY S.E. 1999: The effect of habitat structure on carabid communities during the regeneration of native Scottish forest. Forest Ecol. Manag. 119: 123-36.

Kindlmann P. \& Dixon A.F.G. 2001: When and why top-down regulation fails in arthropod predator-prey systems. Bas. Appl. Ecol. 2: 333-340.

Kindlmann P. \& Dixon A.F.G. 2004: Past and future models of predator-prey population dynamics: the importance of generation time ratio. In Soares A.O., Ventura M.A., Garcia V. \& Hemptinne J.-L. (eds): Ecology of Aphidophaga: Biology, Ecology and Behaviour of Aphidophagous Insects. ARQUIPÉLAGO - Life and Marine Sciences. Bulletin of the University of the Azores. Ponta Delgada, Azores, Portugal, pp. 65-71.

Korner C. \& Diemer M. 1994: Evidence that plants from high altitudes retain their greater photosynthetic efficiency under elevated $\mathrm{CO}_{2}$. Funct. Ecol. 8: 58-68.

Kromp B. 1990: Carabid beetles (Coleoptera, Carabidae) as bioindicators in biological and conventional farming in Austrian potato fields. Biol. Fertil. Soils 9: 182-187.

Kromp B. 1999: Carabid beetles in sustainable agriculture: a review on pest control efficacy, cultivation impacts and enhancement. Agr. Ecosyst. Envir. 74: 187-228.

Leather S.R., Walters K.F.A. \& Dixon A.F.G. 1989: Factors determining the pest status of the bird cherry-oat aphid, Rhopalosiphum padi (L.) (Hemiptera: Aphididae), in Europe: a study and a review. Bull. Entomol. Res. 79: 345-360.

Levie A., Dogot P. \& Hance T. 2000: Release of Aphidius rhopalosiphi (Hymenoptera: Aphidiinae) for cereal aphid control - field cage experiments. Eur. J. Entomol. 97: 527-531.

Liu Y., Yu Z., Gu W. \& Axmacher J.C. 2006: Diversity of carabids (Coleoptera, Carabidae) in the desalinized agricultural landscape of Quzhou county, China. Agr. Ecosyst. Envir. 113: $45-50$.

Magura T., Tóthmérész B. \& Bordán Z. 1997: Comparison of the carabid communities of a zonal oak-hornbeam forest and pine plantations. Acta Zool. Acad. Sci. Hung. 43: 173-182.

Magura T., Tóthmérész B. \& MolnÁr T. 2000: Spatial distribution of carabids along grass-forest transects. Acta Zool. Acad. Sci. Hung. 46: 1-17.

Magura T., Tóthmérész B. \& Molnár T. 2004: Changes in carabid beetle assemblages along an urbanisation gradient in the city of Debrecen, Hungary. Landsc. Ecol. 19: 747-759.

NÈVE G. 1994: Influence of temperature and humidity on the activity of three Carabus sp. In Desender K., Dufrêne M., Loreau M., Luff M.L. \& Maelfait J.P. (eds): Carabid Beetles. Ecology and Evolution. Kluwer Academic Publishers, Dordrecht, pp. 189-192.

Niemelä J. 1999: Ecology and urban planning. Biodiv. Conserv. 8: $119-131$

Niemelä J. \& Spence J.R. 1994: Distribution of forest dwelling carabids (Coleoptera): spatial scale and the concept of communities. Ecography 17: 166-175.

Niemalä J., Haila Y., Halme E., Pajunen T. \& Punttila P. 1992: Small-scale heterogeneity in the spatial distribution of carabid beetles in the southern Finnish taiga. J. Biogeogr. 19: $173-181$.
Niemelä J., Spence J.R., Langor D., Haila Y. \& Tukia H. 1994: Logging and boreal ground-beetle assemblages on two continents: implications for conservation. In Gaston K., Samways M. \& New T. (eds): Perspectives in Insect Conservation. Intercept, Andover, pp. 29-50.

Niemalä J., Haila Y. \& Punttila P. 1996: The importance of small-scale heterogeneity in boreal forests: variation in diversity in forest-floor invertebrates across the succession gradient. Ecography 19: 352-368.

ÖstMAn Ö. 2004: The relative effects of natural enemy abundance and alternative prey abundance on aphid predation rates. Biol. Control 30: 281-287.

Östman Ö., Еквом B. \& Bengtsson J. 2001: Landscape heterogeneity and farming practice influence biological control. Bas. Appl. Ecol. 2: 365-371.

Östman Ö., Еквом B. \& Bengtsson J. 2003: Yield increase attributable to aphid predation by ground-living polyphagous natural enemies in spring barley in Sweden. Ecol. Econ. 45: 149-158.

Pain D. \& Dixon J. 1997: Why farming birds in Europe? In Pain D. \& Pienkowski M. (eds): Farming Birds in Europe. Academic Press, London, pp. 1-24.

RIVARD I. 1966: Ground beetles (Coleoptera: Carabidae) in relation to agricultural crops. Can. Entomol. 98: 189-195.

Robinson D. \& Sutherland W. 2002: Post-war changes in arable farming and biodiversity in Great Britain. J. Appl. Ecol. 39: 157-176.

Schmidt M.H., Lauer A., Purtauf T., Thies C., Schaefer M. \& TsCHARNTKe T. 2003: Relative importance of predators and parasitoids for cereal aphid control. Proc. R. Soc. London (B) 270: 1905-1909.

SIGSGAARD L. 2002: A survey of aphids and aphid parasitoids in cereal fields in Denmark, and the parasitoids' role in biological control. J. Appl. Ecol. 126: 101-107.

Siriwardena G.M., Baillie S.R., CRick H.Q.P. \& Wilson J.D. 2000: The importance of variation in the breeding performance of seed-eating birds in determining their population trends on farmland. J. Appl. Ecol. 37: 128-148.

SÖDERSTRÖM B. \& PÄRT T. 2000: Influence of landscape scale on farmland birds breeding in semi-natural pastures. Conserv. Biol. 14: 522-533.

Southwood T.R.E. 1978: Ecological Methods with Particular Reference to the Study of Insect Populations. Chapman \& Hall, London, $391 \mathrm{pp}$.

Thies C. \& Tscharntke T. 1999: Landscape structure and biological control in agroecosystems. Science 285: 893-895.

Thies C., Steffan-Dewenter I. \& Tscharntke T. 2003: Effects of landscape context on herbivory and parasitism at different spatial scales. Oikos 101: 18-25.

Thies C., Roschewitz I. \& Tscharntke T. 2005: The landscape context of cereal aphid-parasitoid interactions. Proc. R. Soc. London (B) 272: 203-210.

TonTeri T. \& Haila Y. 1990: Plants in a boreal city: ecological characteristics of vegetation in Helsinki and its surroundings, southern Finland. Ann. Bot. Fenn. 27: 337-352.

Weisser W.W. \& Siemann E. 2004: The various effects of insects on ecosystem functioning. In Weisser W.W. \& Siemann E. (eds): Insects and Ecosystem Function. Ecological Studies 173, Springer Berlin, Heidelberg, pp. 3-24.

Wratten S.D. \& Powell W. 1991: Cereal aphids and their natural enemies. In Firbank I.G., Carter N., Darbyshire J.F. \& Potts G.R. (eds): The Ecology of Temperate Cereal Fields. Blackwell Scientific, Oxford, pp. 233-257.

Zhang S.M. \& Zhaо Y.X. 1996: The Geographical Distribution of Agricultural and Forest Insects in China. China Agricultural Press, Beijing, 400 pp.

Received October 3, 2007; revised and accepted April 9, 2008 